\title{
Effect of Biopolymer on Bricks
}

\author{
S. Vasanthapriya, K.S.Divya
}

\begin{abstract}
Compressed Stabilized Earth Brick (CSEB) is a one of the sustainable building material utilizing locally available soils mixed with stabilizers in order to increase its strength. This type of brick mainly consists of soil, sand and a stabilizing agents such as lime, fly ash, chemicals etc. Fly ash brick (FAB) is also a building material containing class $C$ or class $F$ fly ash ,fine aggregate, lime and gypsum .Both the bricks are unburnt bricks which is used to reduce the fuel consumption. In this study, the laterite soil is used and it is stabilized by chemical stabilization which is extensively employed to enhance the physical and mechanical properties of problematic soil. This study examines the effect of xanthan gum which is one of the biopolymer stabilizer in both the compressed laterite soil brick and fly ash brick . Experiments have been conducted by replacing 2\%, 4\% and $6 \%$ of xanthan gum in compressed laterite soil brick and replacing $2 \%, 4 \%$ and $6 \%$ of xanthan gum in fly ash brick partially with cement. The results indicate the potential use of xanthan gum. Tests were conducted on both the bricks and it is compared with normal clay fired brick. It has been shown that $4 \%$ of xanthan gum in compressed laterite soil brick gives high strength of about $8.79 \mathrm{~N} / \mathrm{mm}^{2}$ and $6 \%$ of xanthan gum in fly ash brick give more strength of about $7.31 \mathrm{~N} / \mathrm{mm} 2$.The minimum water absorption is achieved in both compressed laterite soil brick and fly ash brick of about $14.2 \%$ and $10.10 \%$ in the mix of C2 and F3. It promotes a healthier building material and cost reducing not only in production but also in service cost
\end{abstract}

Keywords : Fly ash, Laterite soil, sustainability , unburnt, xanthan gum.

\section{INTRODUCTION}

A brick is one of the oldest and most popular building materials which is used to make walls, pavements and other elements in masonry construction [12].The continuous research and development of bricks has resulted in the production of many types of bricks. Each of the brick is based on physical and mechanical properties, strength , use, finish,manufacture, burning, type etc. One of the cost effective and ecofriendly used bricks are compressed stabilized earth brick (CSEB) and fly ash bricks. They are considered as one of the sustainable building material. Compressed stabilized earth brick (CSEB) are defined as the earthen bricks created by means of compression in hand

Revised Manuscript Received on April 27, 2020.

* Correspondence Author

S Vasanthapriya*, Final year student (B.E), Department of Civil Engineering, IFET College of Engineering, Villupuram, India. Email: vpriya2321999@gmail.com

Mrs.K.S.Divya, Senior Assistant Professor, Department of Civil Engineering, IFET College of Engineering, Villupuram, India. Email: divyachitra27@gmail.com

(C) The Authors. Published by Blue Eyes Intelligence Engineering and Sciences Publication (BEIESP). This is an open access article under the CC BY-NC-ND license (http://creativecommons.org/licenses/by-nc-nd/4.0/) operated or hydraulic machines. It is an environmentally friendly material which is alternative to clay bricks that is used in most of the residential construction in India. The use of stabilized mud blocks is an alternative to burnt bricks, where soil is being stabilized with the stabilizers like cement, lime, molasses etc. and pressing them under high compaction, hence, avoid burning [13]. In avoidance of process of burning, saves a lot of energy and hence, it becomes economical,ecofriendly $[1,11]$.Soil stabilization techniques have been used for improving the properties of soil such as compressive strength, erosion resistance, absorption etc . The process of compaction can further improve the properties of stabilized soil. The process of compaction leads to higher densities, thereby, higher compressive strength, better erosion resistance, lesser water absorption and permeability. The stabilized mud blocks can be used for wall construction, as an alternative to conventional walls [13] . Compressed stabilized earth bricks are also known as pressed earth brick and it is building material made primarily from damp soil compressed at high pressure to form bricks [14]. This brick is mostly stabilized with the chemical binder such as Portland cement and hence it is known as compressed stabilized earth brick (CSEB) or stabilized earth brick (SEB) $[3,7,8]$.

Fly ash brick (FAB) is also a building material containing class $\mathrm{C}$ or class $\mathrm{F}$ fly ash ,fine aggregate, lime and gypsum which is Compressed at 28MPa and cured for 24 hours in a $66^{\circ} \mathrm{C}$ steam bath, then toughened with an air entrainment agent, the bricks last for more than 100 freezethaw cycles $[4,5]$. Owing to the high concentration of calcium oxide in class C fly ash, the brick is described as "self cementing". The raw materials for fly ash bricks are fly ash, sand or quary dust, OPC ( lime+gypsum) [5] . These bricks are lighter and stronger than clay bricks. The manufacturing method saves energy, reduces mercury pollution and the cost is $20 \%$ less than traditional clay brick manufacturing. A waste amount of fly ash as an industrial waste is generated due to the coal used in thermal power plant, which is a major source of electricity. Fly ash is low plastic, fine grained material, susceptible to erosion by both air and water.This study focuses on stabilization of fly ash using biopolymer for air and water erosion by incorporation of xanthan gum.Laterite soils are formed in the tropics through weathering processes that favor the formation of iron, aluminum, manganese and titanium oxides[2]. These processes break down silicate minerals into clay minerals such as kaolinite and illite. Iron and aluminum oxides are prominent in laterite soils and with the seasonal fluctuation of the water table, these oxides result in the reddish-brown color that is seen in lateritic soils [15]. 
These soils have served for a long time as major and sub-base materials for the construction of most highways and walls of residential houses in tropical and sub-tropical countries of the world [13].

It is a main composition of this brick. It has been one of the major building materials for a long time. The use of stabilized soil brick is an alternative to burnt bricks, where soil is being stabilized with the stabilizers like cement, lime, molasses etc. and pressing them under high compaction and hence to avoid burning. It is an environmentally-friendly and low-cost energy materials for sustainable building applications.

This study is important to determine the effect of xanthan gum as biopolymer stabilizer in both the compressed laterite soil brick and fly ash brick interms of its compressive strength, effloroscence and percentage of water absorption.

\section{A. Objective}

The Specific objectives of this work are,

To reduce the consumption of fuel.

To develop the sustainable building material.

To study the effect of biopolymer in compressed laterite soil brick and fly ash brick.

To arrive at the optimum dosage of biopolymer.

To develop the ecofriendly and cost effective building material.

To study the behavior of strength gain in compressed laterite soil brick and fly ash brick.

To determine the effect of using different percentage of biopolymer as cement replacement in compressed laterite soil brick and partial replacement of cement in fly ash brick.

\section{B. Scope of the work}

This study focuses on the effect of xanthan gum on engineering properties of compressed laterite soil brick and fly ash brick in terms of compressive strength, water absorption and efflorescence test.

This study focuses on the effect of xanthan gum on engineering properties of compressed laterite soil brick and fly ash brick in terms of compressive strength, water absorption and efflorescence test.

Performance index of compressed laterite soil brick and fly ash brick incorporated with xanthan gum was then calculated.

The compressive strength, water absorption, efflorescence test, Structure test, Soundness test and hardness test were performed in both the bricks and the result is compared with the fired clay bricks.

The optimum dosage of xanthan gum is then found.

\section{METHODOLOGY}

Collection of materials

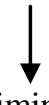

Preliminary test

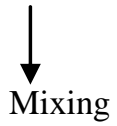

( Dry mixing and wet mixing)

Retrieval Number: D9200049420/2020@BEIESP
Moulding of bricks

( Compressed Laterite Soil Brick and Fly ash Brick)

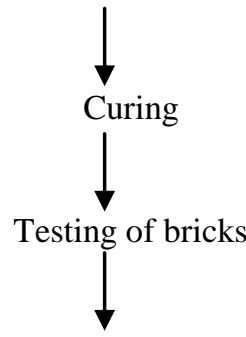

Result and Discussion

\section{A. Collection of materials}

The materials required for making compressed laterite soil brick and fly ash brick are laterite soil, fly ash, fine aggregate, cement and xanthan gum (biopolymer)

\section{B. Xanthan gum}

It is a polysaccharide with many industrial uses,including as a common food additive [9]. It acts as an effective thickening agent and as a stabilizer in order to prevent the ingredients from separating. It is produced from simple sugars using a fermentation process and derives its name from the species of bacteria called Xanthomonas campestris.The chemical formula for xanthan is $\mathrm{C}_{34} \mathrm{H}_{49} \mathrm{O}_{29}$ (monomer) [10].

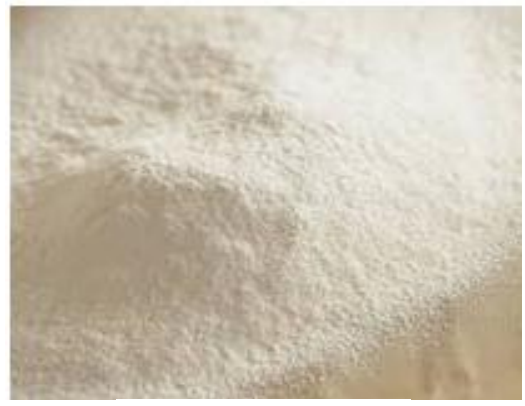

Fig 1. Xanthan gum

\section{Applications of Xanthan gum}

It is used as a joining and creating enzyme in tissue culture of both plants and animals.

It provides less moisture preservation to the dough and retards fat penetration in baked foods.

It improves taste, maintains uniform viscosity, thickening agent and color in dairy products.

It keeps the cosmetics fresh and used as a softening agent in traditional cosmetics.

\section{Preliminary test}

The properties determined include specific gravity, sieve analysis for fine aggregate and laterite soil include Atterberg's limit, Standard proctor compaction and normal consistency, initial and final setting time for cement and viscosity for xanthan gum.
Published By:

Blue Eyes Intelligence Engineering \& Sciences Publication (C) Copyright: All rights reserved.

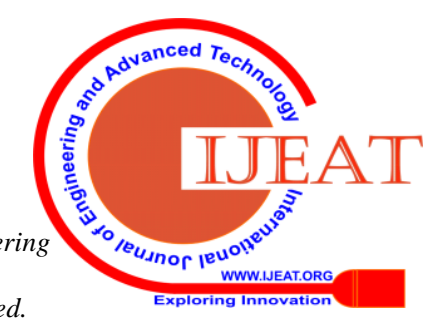




\section{E. Fine aggregate}

Table1. Properties of Fine Aggregate

\section{F. Cement}

Table 2. Properties of Cement

\begin{tabular}{|c|c|c|}
\hline $\begin{array}{c}\text { Test } \\
\text { conducted }\end{array}$ & $\begin{array}{c}\text { Values } \\
\text { obtained }\end{array}$ & $\begin{array}{c}\text { Standard values as } \\
\text { per IS code }\end{array}$ \\
\hline $\begin{array}{c}\text { Normal } \\
\text { consistency }\end{array}$ & $29 \%$ & $\begin{array}{c}25-35 \% \\
\text { (IS 4031-1988 Part IV ) }\end{array}$ \\
\hline $\begin{array}{c}\text { Initial } \\
\text { setting time }\end{array}$ & $33 \mathrm{~min}$ & $\begin{array}{c}30 \mathrm{~min} \\
\text { ( IS 4031- PART V) }\end{array}$ \\
\hline $\begin{array}{c}\text { Final } \\
\text { setting time }\end{array}$ & $600 \mathrm{~min}$ & $\begin{array}{c}10 \mathrm{hrs} \text { ( IS 4031- PART } \\
\text { V) }\end{array}$ \\
\hline
\end{tabular}

\section{G. Laterite soil}

Table 3. Properties of Laterite Soil

\begin{tabular}{|c|c|c|}
\hline Test conducted & $\begin{array}{c}\text { Values } \\
\text { obtained }\end{array}$ & $\begin{array}{c}\text { Standard values as } \\
\text { per IS code }\end{array}$ \\
\hline Specific gravity & 2.64 & $\begin{array}{c}2.75-3.0 \\
\text { IS 2720-1980 }\end{array}$ \\
\hline Sieve analysis & $\begin{array}{c}\text { Cune III } \\
\text { poorly } \\
\text { graded } \\
\text { soil }\end{array}$ & IS 2720-1985 \\
\hline $\begin{array}{c}\text { Optimum } \\
\text { moisture content }\end{array}$ & $16 \%$ & $12-17 \%$ \\
\hline IS 2720-1980 & IS 2710-1985 \\
\hline density & 1.84 g/cc & IS 2720-1980 \\
\hline Liquid limit & $37 \%$ & $53-54 \%$ \\
\hline & $21.05 \%$ & $59-60 \%$ \\
\hline
\end{tabular}

\section{H. Xanthan gum}

Table 4. Properties of Xanthan gum

\begin{tabular}{|c|c|c|}
\hline Description & Values obtained & Standard values \\
\hline $\begin{array}{c}\text { Chemical } \\
\text { composition }\end{array}$ & $\begin{array}{c}\text { Polysaccharide } \\
\text { based }\end{array}$ & - \\
\hline Viscosity & $1415 \mathrm{cps}$ & $1200-1600 \mathrm{cps}$ \\
\hline
\end{tabular}

\section{Mixing}

The mixing process is done with various mix proportions. Soil sample and sand are mixed with various proportions of stabilizer to find the strength of compressed laterite soil brick.

Table 5. Mix proportion of Compressed Laterite Soil Brick

\begin{tabular}{|c|c|c|c|c|}
\hline Mix & Soil & Sand & Cement & $\begin{array}{c}\text { Xanthan } \\
\text { gum }\end{array}$ \\
\hline C1 (\%) & 85 & 5 & 8 & 2 \\
\hline C2 (\%) & 85 & 5 & 6 & 4 \\
\hline C3 (\%) & 85 & 5 & 4 & 6 \\
\hline
\end{tabular}

Soil , sand , cement and xanthan gum were weighted and mixed uniformly as a dry mix .

Next, water was weighted and added into the dry mix based on the optimum moisture content of the laterite soil.

The mix was mixed until the wet mix was uniformly mixed.

Meanwhile, fly ash, cement and sand are mixed with various proportions of stabilizer to find the strength of fly ash brick.

Table 6. Mix proportion of Fly ash Brick

\begin{tabular}{|c|c|c|c|c|}
\hline Mix & Fly ash & Sand & Cement & $\begin{array}{c}\text { Xanthan } \\
\text { gum }\end{array}$ \\
\hline F1 (\%) & 50 & 40 & 8 & 2 \\
\hline F2 (\%) & 50 & 40 & 6 & 4 \\
\hline F3 (\%) & 50 & 40 & 4 & 6 \\
\hline
\end{tabular}

\section{J. Moulding of Bricks}

For a compressed laterite soil brick, the mixed sample is placed in the brick mould of standard size $19 \times 9 \times 9 \mathrm{~cm}$ provided with the manual compress. The mould is lifted up and the bricks are ready when such bricks become sufficiently made for sun drying on the surface for 2-3 days 


\section{Fig2.Compressed Laterite Soil Brick}

For a fly ash brick, the mixed proportion is forced in the mould in such a way that it fills all the corners of the mould of size $230 \times 110 \times 75 \mathrm{~mm}$. Then proper compaction is done using vibrator. The surplus mix was removed either by frame with and top surface was leveled then the vibration is applied using vibrator. Finally the mould is lifted up on the machine and the bricks are ready .

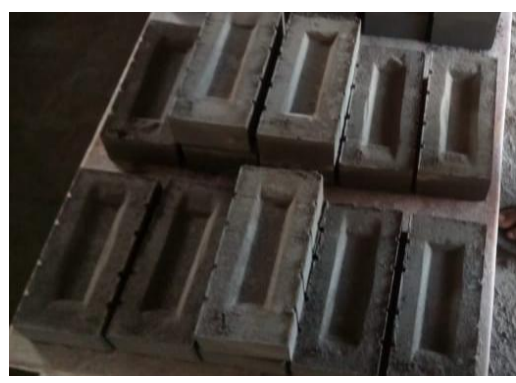

Fig 3. Fly ash Brick

\section{K. Curing}

For compressed laterite soil brick,the curing process was done by spraying each of the samples with water manually every day upto 28 days. For fly ash brick, the wet bricks was kept under air curing for 2 days and then bricks were water cured by spraying each of the samples upto 28 days.

\section{RESULT AND DISCUSSION}

\section{A. Compressive strength}

Compressive strength is the primary physical property to check the suitability of bricks in construction. Compressive strength may be defined as the ratio of compressive load to the area of cross section.

Table7.CompressiveStrength of Compressed Laterite Soil Brick, Fly ash brick and Clay Brick

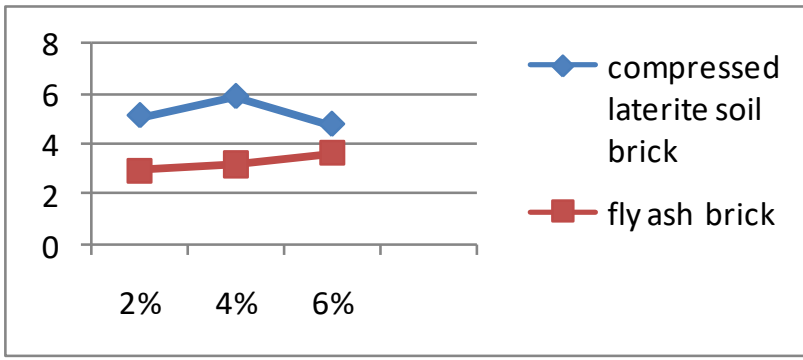

Fig.4. Comparison of compressive strength in 7 days

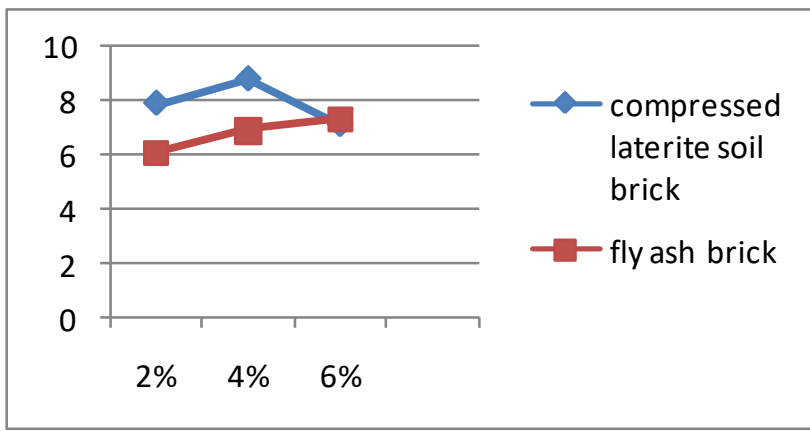

Fig.5. Comparison of compressive strength in 28 days

\section{B. Water Absorption}

Water absorption test on bricks are conducted to determine durability property of bricks such as degree of burning, quality and behavior of bricks in weathering.

The water absorption of normal clay brick is obtained as $16.78 \%$

Table 8. water absorption of bricks

\section{Efflorescence}

Efflorescence is a whitish crystalline deposit on surface of the bricks. Usually magnesium sulphate ,calcium sulphate and carbonate of sodium and potassium are found in efflorescene. For conducting this test the brick blocks are kept in a vertical manner so that it's one end immersed in water. The total depth of brick immersed in water is $2.5 \mathrm{~cm}$. After this the entire arrangements is being kept in a warm water that is to be in a room temperature of $20{ }^{\circ} \mathrm{C}$ to $30{ }^{\circ} \mathrm{C}$ until it gets evaporated. During the process the water placed in the container gets absorbed and the surplus water also gets evaporated, then repeat the process again as before. After completing this process the bricks are examined the total percentageof white spots on the surface of the brick [16]. The efflorescence is obtained as Nil for both the Compressed Laterite Soil Brick and Fly ash Brick as per IS 3495 - 1992 Part III.

\section{Structure test}

One brick is randomly picked from each group and break it.

Published By:

Blue Eyes Intelligence Engineering

\& Sciences Publication

(c) Copyright: All rights reserved.

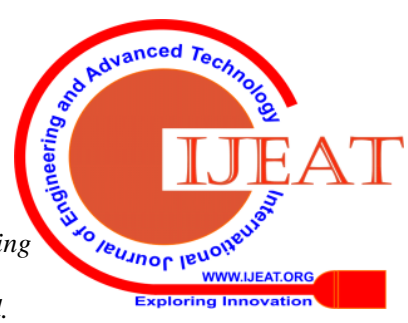


The inner portion of brick is clearly observed. It is then free from lumps and are homogeneous.

\section{E. Soundness test}

It shows the nature of bricks against sudden impact. In this, two bricks are chosen randomly from the compressed laterite soil brick and fly ash brick and struck with one another.The sound produced is clear bell ringing sound and shows that both the bricks are good brick.

\section{F. Hardness test}

A sharp tool or finger nail is used to make scratch on brick and there is no scratch impression on both the compressed laterite soil brick and Fly ash brick then, both are said to be a hard brick.

\section{CONCLUSION}

From this result, it has been concluded that the compressed laterite soil brick and fly ash brick in the effect of biopolymer are more reliable to use in masonry construction. The strength of these bricks war found to be higher than the normal clay brick. It is found that these bricks have higher compressive strength than the clay brick. It has been shown that $4 \%$ of xanthan gum in compressed laterite soil brick gives high strength of about $8.79 \mathrm{~N} / \mathrm{mm}^{2}$ and $6 \%$ of xanthan gum in fly ash brick give more strength of about $7.31 \mathrm{~N} / \mathrm{mm} 2$.The minimum water absorption is achieved in both compressed laterite soil brick and fly ash brick of about $14.2 \%$ and 10.10 $\%$ in the mix of C2 and F3. Therefore these bricks are environmentally better than the clay brick.

Thus the compressed laterite soil brick is used for better living. Its promotes a healthier building material and cost reducing not only in the production but also in service cost of the brick.

These bricks are ultimately greener, ecofriendly, high strength, durable compared to burnt clay bricks.

The optimum dosage of xanthan gum in compressed laterite soil is obtained as $4 \%$ and for fly ash brick is obtained as $6 \%$.

\section{REFERENCES}

1. Trong - Phuoc Huynh, Chao-lung Hwang and Mitiku D. Yehualaw , "Development of compressed stabilized earth block as an eco- friendly and sustainable wall making material" in International Journal of Structural and Civil Engineering Research Vol.7 , No.3 ,August 2018.

2. Fitsum Markos Deboch, " Recent literatures review on stabilization of lateritic soil" in International Journal of Scientific Research Engineering and Technology vol. 7, No 11 , November 2018.

3. Nagaraja A , Shilpa S , Ramakrishna Hedge , "Study on compressed stabilized earth blocks by using chemical admixtures" in International Research Journal of Engineering and Technology vol.5 , No. 6 , June 2018.

4. Vikram and Praveen, " To study the structural properties of clay and fly ash brick masonry" in International Journal on Emerging Technologies , 2017

5. Ankur tayal, Ankit yaduvanshi, Prashant Verma, Abhi Verma, Atul negi, Abhishek Kayasth "Compressive strength of fly ash bricks" in International Research Journal of Engineering and Technology vol.6, No. 5, May 2019.

6. IS 1077-1992 Common burnt clay bricks specification

7. P.J.Walker, "Strength, durability and shrinkage characteristics of cement stabillised soil blocks" in cement and concrete composites vol.17,No.4 .

8. P.Walker and T.Stace, "Properties of some cement stabilized compressed earth blocks and mortars" in Materials and Structures.
9. Lee sojeong chung, "Xanthan gum biopolymer as soil - stabilization binder for road construction using local soil in Sri lanka" in Journal of materials in Civil Engineering, August 2019.

10. Ashwin Balaji P, Ananthan S , Rakesh K, Bharath kumar P, Ms.M.Padmapriya, " Potential of natural Bio - Polymers in stabilization of soil" in International Research Journal of Engineering and Technology vol. 6,No. 4 ,April 2019.

11. B.N.Patowary, N.Nath, I.Hussian ,H.J.Kakoti, "Study of Compressed Stabilised Earth Block" in International Journal of Scientific and Research Publications,Vol.5, No.6, June 2015.

12. Manish Kumar Sahu, Lokesh Singh, Suchi Nag Choudhary, "Critical review on bricks" in International Journal of Engineering and Management Research vol.6,No.5, October 2016.

13. Shanmuka K. N, Manjunath K, Prahallada M.C "Characteristic study of stabilized and compressed laterite soil brick" in NBM \& CW Intra construction and equipment magazine, November 2017.

14. Nagaraja A, Shilpa S, Ramakrishna Hegde "Study on Compressed stabilized earth blocks by using Master cast and Master Emaco Chemicals" in International Research Journal of Engineering and Technology vol.5,No. 6,June 2018.

15. Patrick N. Lemougna, Uphie F. Chinje Melo, Elie Kamse and Arlin B.Tchamba , "Laterite Based Stabilized Products for Sustainable Building Applications in Tropical Countries: Review and Prospects for the Case of Cameroon" in Research gate, December 2011.

16. Prabhat Kumar Singh, Rohit Kumar, Satya Prakash Dash "Study of Compressive Strength of Fly - SH Brick" in International Journal of Engineering research and Technology vol.8 ,No. 6,June 2019.

17. IS 2720-1980 (PART III- specific gravity of soil)

18. IS 2720 -1985 (PART IV-grain size analysis)

19. IS 2720-1980 ( PART -VIII - OMC,MDD)

20. IS 2720-1985 (Atterberg's limit)

21. IS 4031- PART V(initial and final setting time)

\section{AUTHORS PROFILE}

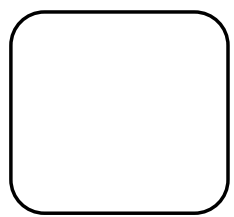

Vasanthapriya S is currently pursuing as a final year student in Department of Civil Engineering, IFET College of Engineering. She has a CGPA of 8.75 upto $7^{\text {th }}$ semester .and has the excellent knowledge in communication stream. She have participated in paper presentation in the topic "Bendable Concrete" schooling in cuddalore. and won second prize. She completed her

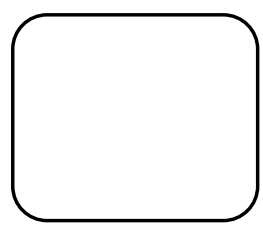

Divya K S, she completed her bachelor degree in Avinashilingam University women, Coimbatore . she received her M.E( Structural Engineering) in Prathyusha Institute of Technology and Management, Thiruvallur. She is currently working as a Senior Assistant Professor in IFET College of Engineering. She has a four years teaching Experience. She has a lifetime membership in "International Society for Research and Development" and "Indian Concrete Institute". she worked for ISO and NAAC auditing. She completed her schooling in Neyveli. 